\title{
Evaluating the Potential Conflicts of Collective Housing Development in the Suburbs of Iași, Romania
}

\author{
Oliver-Valentin DINTER', Lucian ROȘU ${ }^{*}$ \\ * Corresponding author \\ 1 "Al. I. Cuza" University, Faculty of Geography and Geology, Department of Geography, Iaşi, ROMANIA \\ $\triangle$ oliverdinter7@gmail.com (D) https://orcid.org/oooo-0oo2-4922-60o6 \\ $\triangle$ luci_r2003@yahoo.com (D) https://orcid.org/oooo-0oo2-9804-9990 \\ DOI: 10.24193/JSSPSI.2021.8.05 \\ https://doi.org/10.24193/JSSPSI.2021.8.05
}

\begin{abstract}
A B S T RA C T
In the post-socialist transition, the lack of local regulations regarding the development of the peri-urban area of Iași municipality led towards a chaotic and fast-growing residential expansion. The increasing trend of complexes of collective housing built-out in the outskirts brought new conflicts and enhanced the existing ones, altering the territorial identity and social cohesion of the community. The main purpose of this paper is to deliver a better understanding of the drawbacks determined by the occurrence of these complexes and to analyse the spatial intensity and variation of the conflicts. To determine the probability to generate conflicts for each residential project, an index was computed based on conflict triggering factors. The results display the spatial patterns of different conflict types throughout the peri-urban area of Iași. Conflicts are generated by lowering the price of households with a drawback at fostering the already existing conflicts. Major complexes of collective houses are, in general, the most expensive but they generate a lower score for triggering conflicts, while small or individual complexes, even though they are cheaper, tend to create the most common conflicts. While world planning trends aim at enhancing a sense of community through a balanced planning of the suburbs, in the specific case of Iaşi municipality, the lack of planning and the chaotic apparition of residential projects leads to a more segregated and disrupted community, therefore enhancing more conflicts.
\end{abstract}

\section{INTRODUCTION}

Suburbanization is a relatively new phenomenon for Eastern Europe (Sheppard, 2000), developing fast and mostly chaotic in the last 30 years (Stanilov and Sykora, 2014). As opposed to Western countries, socialist cities had a very clear delineation of the limits of the built-up area, creating a sharp transition from high density neighbourhoods to a rural periphery, characterized by agricultural practices, modest villages and low quality of life (Hirt, 2007). Before the end of socialism, most cities faced a major demographic accumulation as a result of forced industrialization (Hirt, 2013) and an increasing workforce demand (Light and Young, 2010). Therefore, the process of suburbanization, after the fall of communism, evolved at a very high rate.

Naturally, the end of socialism and liberalization of the real estate market led toward a fast peri-urban residential growth, mostly due to a general need for better living conditions. This fast change of the suburbs in only a few decades remains the most important transformation that affected the living style in Eastern European cities. The new situation, with a profound change of both the economic and political mindset, led to an intense reorganisation of urban areas 
(Stanilov, 2007). Few processes arose, such as the transition from monocentric to polynucleated cities (Bertaud, 2006) and spillovers - the extension of the city beyond its administrative limits. A distinct area, the emergence of suburbs steered towards an alteration of both landscape and rural identity. Therefore, new issues in terms of environment, structure, life quality, social interaction, etc. (Brown and Raymond, 2007) have been triggered by the emergence of recent development trends. The fast-changing transition from rural to urban status in a very short time may lead to conflicts, disputes, and cultural clash.

For Europe, suburbanization has some characteristics such as multiple-family housing, less pollution and a general feeling of open space (Madaleno and Gurovich, 2004), even though distance to most facilities is very probable much higher. Actually, most developed capitalist states have a certain pattern for the concept of suburbanization, migrating from the core city to suburbs, meaning that most probably their inhabitants are from upper and middle class (Hirt, 2007). In developing nations, the process is different, most of the inhabitants settling as a consequence of rural to urban-migration and part of the lower class (Korcelli, 1990).

Romania is in between the two abovementioned processes, the process of suburbanization being slightly different from that in other countries from Eastern and Central Europe (Dumitrache et al., 2016). To understand suburbanization, researchers who analysed different characteristics of the process concluded that multiple factors are strongly related: the administrative planning of the territory, the communist legacy, the trends on ownership rights and the transition from industrial market towards tertiary services.

In this context, the impact of economic, political, and social changes on suburban land use has been significant and resulted in the occurrence of a new and complicated form - the suburb - a transition from urban shape to quiet residential areas. While theoretical studies have exploded in the last decade, analysing various characteristics of the suburbs, the suburbs generated a unique and distinct territory: a social and cultural mix between local communities and newcomers, a chaotic development of residential buildings, a complex functional area, and, lately, the emergence of complexes of collective housing which alters the sense of suburbs.

An already shaped territory by diverse processes, it now faces the challenge of building complexes of collective housing, bringing with them conflicts of different types, such as social, economic, environmental, and administrative. Even though territorial conflicts between different land uses, including suburbs, have been questioned by various researchers, the recent occurrence of collective residential projects has complicated even more the definition of suburbs. Little is known about the effects generated by the apparition of collective residential real estate projects in a territory which, traditionally, was populated by individual houses, having not received sufficient attention neither from researchers, nor from the stakeholders involved in the process.

Thereby, the focus of the present research is to analyse the conflicts generated by the recent occurrence of residential collective buildings in the suburbs, pleading that, along with this new type of habitation, the pressure on the environment becomes even more difficult to manage and to understand. In order to highlight the conflicts, the methodological framework consists of an integrative approach which includes the evaluation of the different characteristics of the new collective buildings related to the surroundings and to the city, using specific GIS techniques. Furthermore, using a hierarchical analysis, the results are then compared with the price per square metre of each residential project, in order to evaluate how financial possibilities help overcome possible conflicts.

The analysis is of great importance for scholars as it reveals new conflicts generated by residential collective projects. Territorial planning stakeholders are very interested in consolidating and deepening the knowledge and understanding regarding the research area as their main purpose is to avoid malfunctions and to stop chaotic urban sprawl, redesigning and rethinking towards a sustainable urban landscape.

\section{THEORY AND METHODOLOGY}

\subsection{Conceptual framework}

Due to its complexity, urban expansion is a research subject for numerous activity fields and it is being analysed using specific methods for every domain. Depending on the used techniques, recent studies aim to emphasize the negative effects of this heterogeneous process that produces numerous conflicts. In order to determine the drawbacks of periurbanisation and also to provide adequate solutions to the identified causes, scholars conducted various studies using satellite images, sociological approaches, economic models, GIS methods or statistical indices.

Remote sensing has gained more popularity in monitoring the land use conversion of the urban fringe, being able to deliver the locations of potential conflicts and could be correlated with other types of data to fulfil complete conflict assessments. Bîrsănuc, Man and Petrea (2019) investigated the impact of the built-up area expansion onto the land use categories of Cluj Metropolitan Area over a 26-year period by reclassifying the Soil-Adjusted Vegetation Index using land cover datasets. Results highlighted two spatial patterns: Zone A with an accelerated urbanisation and 


\section{Evaluating the Potential Conflicts of Collective Housing Development in the Suburbs of Iași, Romania Journal of Settlements and Spatial Planning, Special Issue, no. 8 (2021) 49-63 \\ Territorial Identities and Sustainable Development. Challenges and Solutions}

Zone B with a slow expansion rate (Bîrsănuc, Man and Petrea, 2019), that were confirmed by the correlation with demographic and building permits databases. The authors exhibit the negative effects of urban sprawl: "crowdedness [...] increase in the risk of landslide occurrence, climate change and reduction of economic benefits from land agricultural exploitation" (Bîrsănuc, Man and Petrea, 2019, p. 128), which could trigger conflicts that irreversibly affect the social, economic and the landscape identity of the peri-urban space. Built-up area expansion patterns could be investigated using machine-learning algorithms as well. A study performed by Kontgis et al. (2014) in the Ho Chi Minh City metropolitan area provides an example of Landsat imagery processing using supervised Support Vector Machine classifier, which delivers more accurate boundaries between land use classes. The division of the communes into three classes (urban, peri-urban and rural) and the correlation of classification results with demographic data from 1990 to 2012 unveiled that periurban localities recorded the most intense built-up and population growth (Kontgis et al., 2014).

From the point of view of territorial identity, there are many studies focusing on analysing the sense of place or the identity of places (Kalandines, 2011). Banini (2017) defines territorial identity as "a process of social construction, open and dynamic, through which the collectivities settled in a given territory choose the distinctive features of the territory they inhabit or where they act in, shaping shared values, solutions, actions, and future trends" (p. 18). While most of the studies are focusing on traditional spaces and developed new methods in understanding place (Ilovan and Maroşi, 2018) as benchmarks for understanding territorial identity, few studies challenged the territorial identity of places in transition (Wójcik, 2013).

Periurban sprawl led to fast structural and social changes which have a huge impact on the understanding of the social attributes of analysed territory. Sociological research mainly focuses on the negative effects that the peri-urbanisation exerts on people. The construction of new residential complexes of collective housing shapes the initial landscape in a manner that directly affects the rural identity of the area. As a consequence, conflicts may arise due to the different perspectives in terms of space management and lifestyle between rural dwellers and new residents that relocated from the city core (Bailoni, Edelblutte and Tchékémian, 2012).

Wójcik (2013), in his paper titled "Territorial Identity of Countryside Residents in the Suburban Areas of Łódź, Poland”, conducted questionnaire interviews, which revealed that "over $90 \%$ of long-time residents [...] felt a bond with the village and the local community" (Wójcik, 2013, p. 76), while new residents reported an indifference regarding the local community. Moreover, respondents mentioned only few positive aspects of village transformations (population and entrepreneurship growth) and numerous drawbacks (expansion of construction, low management of open spaces, heavy traffic, presence of numerous fences, new residents' undesirable behaviour, etc.), denoting a wide spectrum of conflicts that may determine "social disintegration" and "mutual distrust of human groups" (Wójcik, 2013, p. 77).

Larcombe et al. (2019) expose the impact of the conflicts generated by collective housing on residents' mental health. A multi-storey building in a low socioeconomic area determines "polluted air quality, unsafe heating systems, the presence of toxic substances, pests, and overcrowding" (Larcombe et al., 2019, p. 3), leading to health problems, while smaller areas of green space, noise, poor maintenance of buildings and higher insecurity levels directly cause psychological problems to all residents. Moreover, authors confirmed that people living on upper floors experience more mental health problems than those living on lower floors, especially because of the higher isolation degree (Larcombe et al., 2019), stronger in the peri-urban area due to the insufficient facilities.

Economic models in Real Estate Geography are implemented to quantify attributes that people consider when buying a housing unit, but do not pay directly for. If a potential buyer could enjoy the proximity of economic, leisure or educational facilities, he or she would not pay a specific price for each of them, but the final market value will include the sum of these attributes (Orford, 1999). By assigning a price for every variable, it is easier to determine which ones bring more value to the commodity. Some approaches value either the benefits of living in the peri-urban space compared to the urban area or the compromises people are willing to make to obtain a better price.

A study undertaken by Lityński and Hołuj (2017) aims to estimate the average (daily and annually) losses caused by the "chaotic suburbanization" in Poland in terms of both time and money, using several indicators related to time/distance to and from the city by car and public transport. The research also forecasts high losses per household in the period 2017-2030 for each of the analysed cities, which could be reduced by improving spatial management policies (Lityński and Hołuj, 2017). Caruso, Rounsevell and Cojocaru (2005) stated that the peri-urban spatial configuration is an outcome of both economic and hedonic factors as "level of income, transport costs, and preferences for local amenities" (p. 108). The authors valued social and landscape attributes by assessing the neighbourhood density, alongside with the income of the potential new residents in the southern commuting area of Brussels. The results revealed that newcomers value the landscape 2.5 times more than the social attributes (Caruso, Rounsevell and Cojocaru, 2005), highlighting the importance of the space. As a consequence, conflicts 
related to the location of residential units are considered to exert a stronger impact.

Studies that perform GIS methods emphasize the importance of the location, analysing how the intensity of different phenomena varies within an area and may raise awareness on measures that could be taken in order to reduce the intensity of the conflicts. Manaugh and El-Geneidy (2011) correlated various walkability indices on different pedestrian network buffers in Montreal with people's travel trends, depending on ,individual, household and trip characteristics". Notable differences were being observed between areas of wealthy residents and areas with both low-income households and low car access (Manaugh and El-Geneidy, 2011). In the peri-urban space, walkability differences could be recorded between complexes that feature diverse services and remote residential buildings, which lack access to facilities and increase car dependency, leading to various conflicts. Pigawati Yuliastuti and Mardiansjah (2019) analyse the spatial residential distribution and density in Semarang, Indonesia. The authors performed a nearest neighbourhood analysis to identify the patterns of housing distribution. The clustered type was considered the most conflictual due to the intense land conversion, unsuitable topographic conditions and lower class inhabitants (Pigawati, Yuliastuti and Mardiansjah, 2019). Moreover, extremely-dense residential areas could lead to pollution as well. The final remarks confirm the importance of developing policies in order to prevent chaotic residential growth.

Statistics comprise practical tools in computing indices that facilitate comparisons between current and previous situations. A new regression type (Geographic Weighted Regression) performs various equations (instead of a global regression) on a single study area, based on neighbourhood values. Its results could be mapped to display the locations of potential conflicts. Grădinaru, Iojă and Pătru-Stupariu (2015) provide a statistical instrument that detects periurbanisation patterns of Romanian cities (based on land cover datasets for 1990 and 2006) by computing four indicators (Centrality Index, Compactness Index, Compactness Index of the Largest Patch and Porosity). The obtained values confirmed the suburbanisation for most urban areas, which is stronger in the case of Rank $O$ and 1 cities and may lead to conflicts in terms of "sustainable development of the urban landscape due to its connections with exception driven urbanism, abandonment of agricultural land and excessive development in areas with low connection to public transportation" (Grădinaru, Iojă and Pătru-Stupariu, 2015, p. 140).

Another approach by Liu and Robinson (2016) determined the impact of the amenities that drove the residential patterns of the peri-urban area of Adelaide from 1971 to 2010. The explanatory variables included in the Geographic Weighted Logistic Regression were the distance to major roads, CBD, schools, hospitals, coast, and parks, as well as the elevation and the density of residential space. The distribution of GWLR values throughout the study area was mapped for each of the four analysed decades and for every parameter. An example could be the distance to major roads, schools and hospitals that recorded a decreasing negative influence from 1971 until 2010 (Liu and Robinson, 2016). Generally, the negative values of the GWLR indicate the locations that may face conflicts generated by the lack of specific attributes. Liu and Robinson (2016) included accessibility indicators (distance to main roads, CBD, hospitals, schools, parks, and coast) which highlighted a solid correlation between the road expansion and built-up patterns of Adelaide's urban fringe (except the case of hospitals and schools).

Various indicators and methods have been used by researchers in their attempt to analyse the periurban area. Accessibility instruments as average speed, distance and time spent in traffic from the peri-urban communes to the city centre of Iaşi were used by Blăgeanu, Iacob and Roșu (2012), whose results revealed that the suburbanization process is more visible in areas that record higher values in terms of accessibility. Hedonic methods are specific in real estate valuation, quantifying the structural and locational attributes that provide utility to the owner. Orford (1999) emphasizes the influence of positive (parks, rivers) and negative (railways, industrial sites) locational externalities upon the housing price, which varies within the city of Cardiff depending on the distance from the apartment to the above-mentioned facilities. Land-use changes from arable to built-up land are monitored using remote sensing. Grădinaru et al. (2015) correlate the residential development with various explanatory variables, one of those being the former land use, whose abandonment increased the emergence of buildings in the periphery of Bucharest. As a result, highest values were being recorded in the case of agricultural land if compared to other land use types. Iojă et al. (2013) confirm this tendency, which is stronger in the peri-urban area of the aforementioned city than in the communes located further away and record a higher probability of facing land use conflicts.

Different methods are used to reveal potential conflicts generated by the development of suburbs and some researchers use integrative methods. The present article takes into consideration diverse methods in order to create an index which measures the potential conflict generated by high-rise apartments in the suburbs of the Iaşi Metropolitan Area. Although the vast majority of peri-urban studies include 1 or 2 variables in their research, this paper brings as a novelty the compilation of several indicators which are responsible for the emergence of a large palette of conflicts specific to this area. 


\subsection{Research on urban sprawl phenomena in Romania}

A series of scientific analyses concerning the Romanian metropolitan areas (Suditu et al., 2010, 2014; Iojă et al., 2011; Grigorescu et al., 2012; Ianoş et al., 2012; Grădinaru, Iojă and Pătru-Stupariu, 2015) were conducted in order to disclose the spatial patterns of the urban growth and the changes caused by this process. However, these studies focused on the common challenges most cities were facing, partially revealing local characteristics. Suditu et al. (2010) and Grigorescu et al. (2012) emphasize the political, demographic, and natural drivers of the urban sprawl, the extent of this phenomenon and the effects it has onto the land use patterns, as well as the necessity of improving spatial planning and management to grant a higher quality of life and less conflicts.

Reviewing the studies which focus on a specific urban area in Romania, it could easily be observed that the most numerous are treating the case of Bucharest, using various methods: satellite image analysis correlated with land cover or statistical data (Sandric et al., 2007; Suditu, 2009; Simion, 2010), sociological instruments (Stan, 2012), statistical methods (Grădinaru et al., 2015) or multi-criteria analysis (Iojă et al., 2012, 2014). These studies are undertaking a complex assessment on the quality of the environment in the residential areas of Bucharest and its periphery, identifying the typologies of these spaces, their natural characteristics, vulnerabilities, environmental problems that may appear, as well as parameters used in the analysis and solutions to environmental changes. Grădinaru et al. (2015) computed two regression models using several indicators that might predict residential development in order to emphasize the role of agricultural land abandonment in this process, while Iojă et al. (2013) performed a multi-criteria analysis to reveal the locations of the land-use conflicts in the Bucharest Metropolitan Area. The latter study unveils that areas which are most prone to conflicts share a border with the Capital city, featuring the highest rates of built-up and residential areas growth, as well as population increase.

The analysis of second tier cities' peri-urban areas was not approached by many authors. Therefore, this paper covers the issues that cities which fall into this category are confronting, which tend to differ from the situation of Bucharest or small towns. However, there are some papers that research urban sprawl, an example being provided by Bîrsănuc, Man and Petrea (2019), whose analysis discloses two patterns of urban sprawl in Cluj Metropolitan Area, one in which the arable land is affected and grasslands in the other one, these land use conversions leading to conflicts in terms of environment and landscape identity, especially in areas that experience population growth.
Regarding the peri-urban area of Iași Municipality, different methods were used in monitoring urban growth, out of which we mention spatial analysis (Iacob, Roşu and Blăgeanu, 2012), satellite images (Ursu et al., 2016) and accessibility instruments (Blăgeanu, Iacob and Roşu, 2012). The first one was achieved using the Cellular Automata model in order to predict spatial trends of the urban growth in Iași and Cluj-Napoca Municipalities based on remote sensing. In the case of the first city, four relevant areas were detected in the northern, eastern and southern parts, extending to the neighbouring communes.

Ursu et al. (2016) used satellite images as well as orthophotomaps to identify the patterns of built-up area expansion (proximity to main roads or to leisure areas, natural factors), as well as land use conversion, from "former industrial areas into commercial, real estate areas, or the densification of these urban areas" (Ursu et al., 2016, p. 203).

Using accessibility methods, Blăgeanu, Iacob and Roşu (2012) analysed the suburban communes, highlighting that the most intense process of development was recorded by the areas located within 20 minutes to the city centre. The authors predicted that the future highway to be built in the northern part of the city would not enhance the urban sprawl, but the improvements in terms of road infrastructure of the communes in the eastern part of the city would increase their attractiveness, especially of the ones located closer to the urban area.

\subsection{Study area}

Iași Municipality, former capital of the Principality of Moldova is, nowadays, the second largest city of Romania ( $1 / 2$ million inhabitants for the metropolitan area) and the main engine of the North East development region due to the appreciated social, economic, and educational opportunities. Even though it has a peripheral spatial position in the local, regional, and national system, it still plays a very important role in the diffusion of innovation due to its size and vibrant emergent economy. At the national level, Iaşi Municipality is considered a second-tier city (ESPON report, 2012), having similar characteristics to other Eastern European cities (Roșu and Blăgeanu, 2015).

The present study considers the Functional Urban Area of Iaşi. Iaşi Municipality had a compact form until the late 1990s, the extension being mainly vertical, creating an even more densified urban form, which is nowadays considered to be sustainable (Burton, Jenks and Williams, 2013). Since the fall of communism, things have changed and Iaşi Municipality faces a post-socialist transition (like all major cities in the eastern EU), the main morphologic and social changes being addressed at the fringes of the city. There is an obvious relocation of industry in the outskirts of 
the city, together with retail services and the development of the individual residential houses.

All these features, combined with the lack of legislation and misleading rules for a planned territory, enable a chaotic urban sprawl. This intensification of the phenomena led to a change of perception upon suburban areas, easily becoming a less desirable place to live, in contrast with the attractive identity of the traditional village, governed by the prevalence of nature (Tobiasz-Lis and Wójcik, 2017).

This change of social status leads to lowering prices for the suburbs and a constant demand for cheap solutions. Iaşi Municipality, in the last years, faces a new type of settlement in the suburbs. The construction of collective residential buildings, a trend that appeared during the last five years, contributes even more to the downfall of the quality of life provided by living in the suburbs. The lack of urban planning and the lack of knowledge in understanding the dynamics of the suburbs drive towards strengthening a monocentric system (Mihai, 2015), while nowadays trends are to plan the future for polycentric systems.

The demographics of Iaşi Municipality (Fig. 1) reveals that the growth is based on its polarisation forces that attract more and more people from the surrounding area due to economic and educational factors. The annual growth rate for Iaşi Metropolitan Area is $6 \%$, most of the communes together with this having a constant growth in the last twenty years.

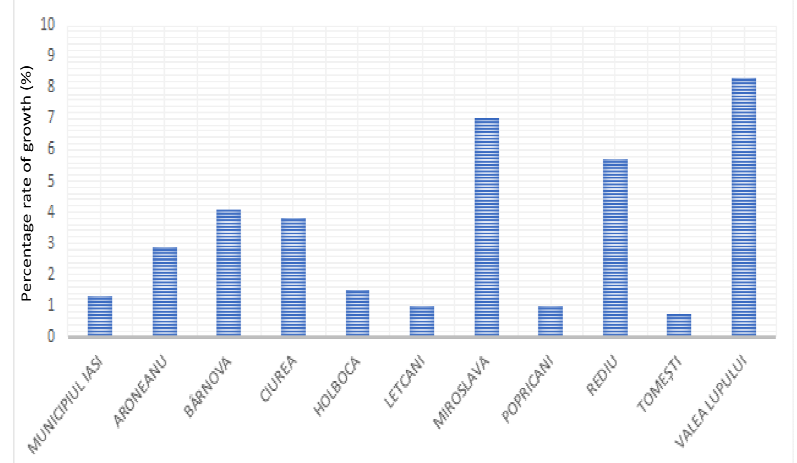

Fig. 1. Annual average growth rate of population in Iaşi Metropolitan Area (2010-2020).

Taking into account all the above-mentioned factors, nowadays, urban sprawl has generated more problems than its initial role - to create the context for a higher quality of life. Researchers have shown that the suburbs of Iaşi Municipality are prone to massive traffic jams (Ursu et al., 2015), low air quality (Roşu, Istrate and Bănică, 2018) and can easily generate social and cultural conflicts. These issues are generated by the lack of a resilient planning of the suburbs, supplemented by an obvious car dependency model and a lack of integrated metropolitan public transport.

\subsection{Data and methods}

In order to reach the goal of the present research, several data were collected, statistically processed and introduced in GIS, where spatial statistics models were applied. Our observations consider 66 new collective residential buildings, most of them built in the last six years and located in the outskirts of the city, in the peri-urban area of Iaşi city.

For each residential building, various indicators were calculated to evaluate their impact upon the environment, as follows:

a). Time spent in a car while driving towards the central zone of Iaşi Municipality at rush hour (8-9 AM) - this value was calculated using Closest Facility function in Network Analyst (ArcMap 10.4.1) and evaluated with Google Maps, which computed the average speed for each segment route.

b). Walkability Index - evaluates how many facilities (and their diversity) are in a service area of $500 \mathrm{~m}$ (10 minutes' walk). The investigated facilities (Table 1) were those related to educational services (schools and kindergartens), transportation (public transport stations), economic facilities (supermarkets, pharmacies, cafés, restaurants, and other services), leisure ones (urban parks, green areas, sports facilities) and other (religious facilities). An Index was created based on the different weight of each service type. The weight considers the frequency of each facility.

Table 1. Weights selected for the facilities included in the Walkability Index.

\begin{tabular}{|l|l|r|r|}
\hline \multirow{4}{*}{ Facility } & \multicolumn{2}{|c|}{ Weight } \\
\hline \multirow{4}{*}{ Economic } & Shops & 0.02 & \\
\cline { 2 - 3 } & Pharmacies & 0.05 & \multirow{4}{*}{0.15} \\
\cline { 2 - 3 } & Personal care & 0.04 & \\
\cline { 2 - 3 } & Pubs & 0.02 & \\
\cline { 2 - 3 } & Others & 0.02 & \\
\hline Leisure & & 0.25 \\
\hline Transport & & 0.2 \\
\hline Education & & 0.3 \\
\hline Religious & & 0.1 \\
\hline
\end{tabular}

c). Pressure Index - number of available apartments per project. This index reveals the pressure generated by a large number of inhabitants which induces higher air pollution, higher values for noise, higher traffic generated by inhabitants and a general higher pressure upon the environment.

d). Public Transport friendliness - distance toward the closest bus station calculated using the Closest Facility instrument.

e). Ecological indicator - the land use change obtained from Google Earth Pro historical imagery. It takes into account if the previous land use was able to 
provide resources and natural services (Mulder, Costanza and Erickson, 2006) before being occupied by a collective residential building. The exploitation of forests, parks and agricultural land use reveals a high negative impact upon environment and place attachment as well (Brown and Raymond, 2007), which is related to the territorial identity of the suburbs.

f). Visual blight indicator - conflict caused by negative visual impact of high-rise apartments, calculated as average difference of height between site and surrounding buildings $(250 \mathrm{~m}$ ) in order to evaluate visual discrepancy (von der Dunk et al., 2011).

g). Financial accessibility - price per square metre of each individual residential project.

To evaluate the conflicts generated by every residential project, the values obtained for each indicator were normalized using numbers from o to 100,0 being regarded as the least conflictual and 100 as the most conflictual. Then, using the Grouping Analysis tool from ArcMap 10.4.1, a multivariate analysis was performed, all 66 complexes being differentiated into four classes according to the values recorded for every indicator taken into account, each class featuring only residential projects with the highest similarity degree and prone to generate conflicts of the same category. As a result, it was possible to determine spatial patterns of different types of conflicts according to the locational and structural attributes of the analysed complexes of collective housing. A report was generated separately by the tool in order to facilitate the map interpretation, a series of charts being available to show in a comparative manner how the values of the indicators vary from one group to another and also what are the most probable conflicts generated by each class.

Finally, a Conflict Index was created for each residential project, summing up all indicators presented above, and the result was correlated with the price per square metre in order to discover if the probability of a complex to generate conflicts may affect the sale price. Based on the Regression tool provided by Microsoft Office Excel, it was also appreciated if the Conflict Index can be predicted by knowing the value of the apartment (price per square metre).

Moreover, it was necessary to correlate each indicator with the price per square metre in order to evaluate which of these exert a greater influence on the price and may also generate possible conflicts. To reach this goal, a correlation analysis, defined as the "association or relationship between two (or more) quantitative variables" (Gogtay and Thatte, 2017, p. 78), was satisfactory enough to assess the strength and the direction between the variables.

\section{RESULTS AND DISCUSSION}

The geographical position of the 66 collective housing complexes reveals that the analysed objects are in the outskirts of Iaşi Municipality, mostly in an already established individual residential neighbourhood (Fig. 2). Few factors are responsible for the emergence of these buildings.

The most important are the trade-off theory (Basset and Short, 1980) and the access-space trade-off model (Maclennan, 1982), which describe the minimization of households trade-off travel costs to the city centre, against housing costs in an attempt to maximise utility subject to an overall budget constraint. Based on this theory, the most important attributes are related to the availability of space and the proximity of major routes in order to solve accessibility to the city centre. Therefore, most of the collective buildings are located as close as possible to the city outskirts, but are challenged by availability of space and desire to live in an attractive place.

Since 2008, a new trend emerged in the construction of buildings, namely the rise of residential collective buildings in the suburbs, with a record in 2021, despite specific problems generated by COVID19. The north-west and west areas of the city are the most active in this matter, along with the southern area where the emergence of residential projects puts great pressure on the environment (Fig. 2).

While most residential projects have a relatively small number of apartments, the trend in the recent years reveals that there are some few major investments in building large residential projects with some facilities included, inducing a higher price. This is a result of the monocentric structure of the city which does not have a strategic plan to offer facilities at the periphery.

While major residential projects offer a higher liveability, they also tend to damage the environment more and are prone to various conflicts, as it will be presented below. Another effect is the tendency to a concentration of future residential projects in the proximity of older ones, changing profoundly the landmarks of the suburbs.

\subsection{Conflict Index}

As mentioned above, the analysis mainly focused on computing an index based on the values of potential conflict triggers in the peri-urban area. The spatial distribution of the results unveil that the Conflict Index tends to increase according to the distance to the city centre. Therefore, the lowest conflict scores could be encountered in the case of the collective complexes located closer to the urban core, especially in the northern part of the city.

Thus, the highest prices per square metre are recorded for these residential developments, which benefit from the proximity of the cultural area of Iaşi, the prestige bringing a premium that is included in the sale price (Fig. 3). The relatively satisfactory 
Oliver-Valentin DINTER, Lucian ROȘU

Journal of Settlements and Spatial Planning, Special Issue, no. 8 (2021) 49-63

Territorial Identities and Sustainable Development. Challenges and Solutions

accessibility does not ensure that these complexes lack drawbacks. While the Conflict Index may go up to 25 (or even exceeding this value in some cases), land use change may represent a source of conflicts.

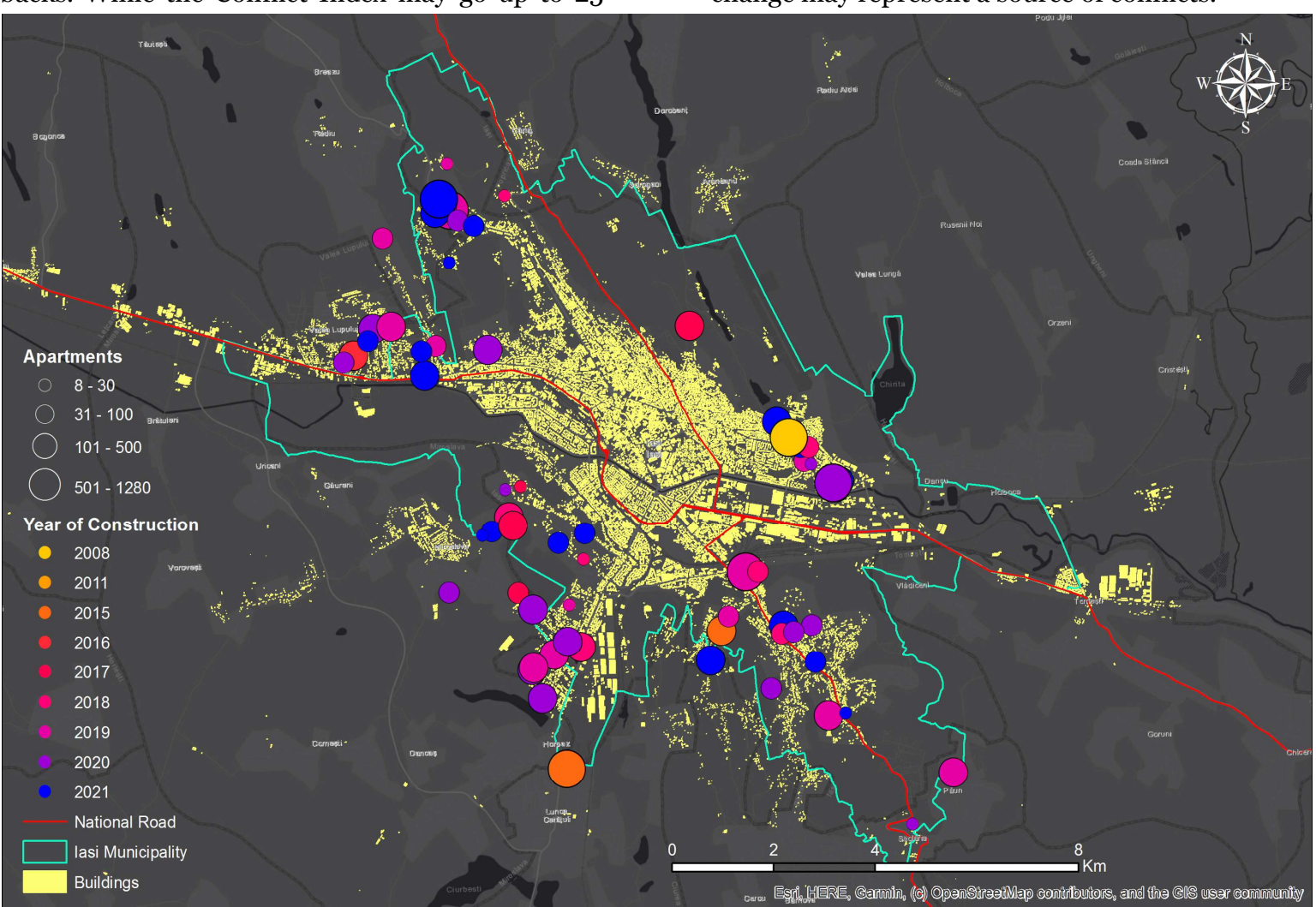

Fig. 2. Complexes of collective housing in the peri-urban area of Iași Municipality.

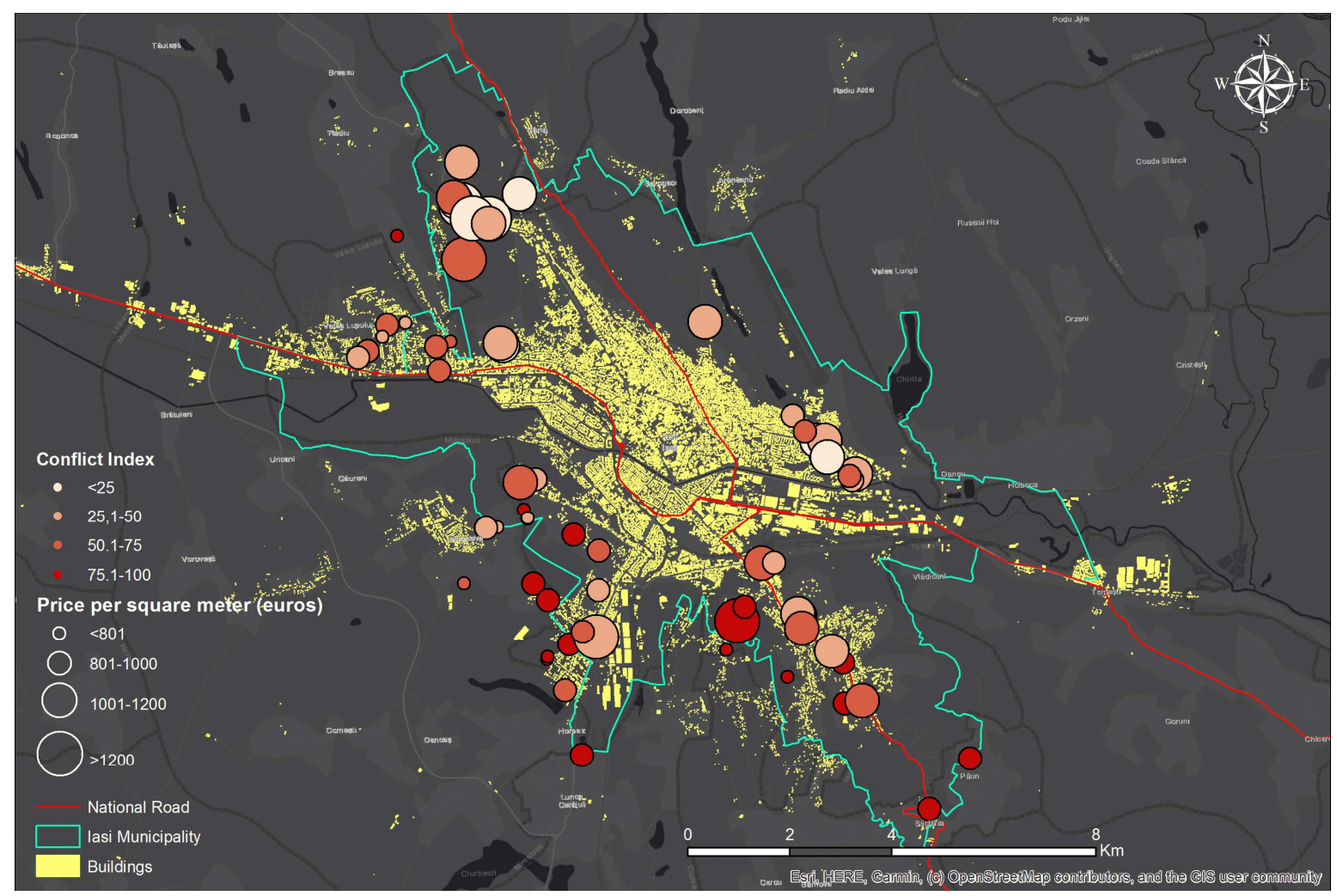

Fig. 3. Conflict Index of the complexes of collective housing in the peri-urban area of Iași Municipality.

The Conflict Index values below average (from 25 to 50) are distributed in the most peri-urban areas, 56 either at the edge of the urban core or in the proximity of the main access roads to the city from the 


\section{Evaluating the Potential Conflicts of Collective Housing Development in the Suburbs of Iași, Romania Journal of Settlements and Spatial Planning, Special Issue, no. 8 (2021) 49-63 \\ Territorial Identities and Sustainable Development. Challenges and Solutions}

neighbouring communes, which demonstrates the decisive role of accessibility (Fig. 3). The prices of complexes that fall into this category tend to exceed 1,000 Euros per square metre for those that benefit from a better position in relation to the city core and drop below this value for the buildings placed closer to (or even inside) the rural settlements.

Regarding the complexes of collective housing that obtained a score above average, it could easily be observed that most of them are located in alternation with the ones from the previous category, so the accessibility is comparable. The increased probability of conflicts in this case could be a result of more aggressive land use changes or unfavourable structural attributes like the high number of apartments or floors compared to the neighbouring buildings. These residential developments tend to be valued at similar prices with the ones in the previous category (slightly above or below 1,00o Euros per square metre) as they are located in similar sites.

The buildings most prone to conflicts are especially those located in undeveloped sites, close to the border between the city and the neighbouring communes. Moreover, they record the longest distances to the city centre and a considerably low value of neighbourhood density which brings a reduced walkability potential due to the lack of facilities. All of these combined with the inadequate land suitability lead to prices below 1,00o Euros per square metre and the highest share of complexes that cost below 800 Euros from all the categories mentioned above. Consequently, people that are willing to pay less for a home in a collective complex from this category should consider the increased probability of facing conflicts and losses in terms of time and money due to the lack of facilities that more expensive complexes already have.

\subsection{Multivariate analysis}

The results of the multivariate analysis delivered four classes of complexes of collective housing based on the similar values of the indicators considered as conflict triggers, regardless of their position throughout the peri-urban area (Fig. 4).

Starting with the Blue Class, the most probable conflict is represented by the land use changes which obtained the highest average values for this indicator from the four resulted categories. Spatial distribution of the complexes that fall into this class reveals a cluster of seven residential units in the northern part of the city, on a site that was previously famous for the vineyards. As mentioned in the previous section, the price per square metre of these complexes is the highest in the peri-urban area of Iaşi Municipality, also due to the view that the residents could benefit from, as the former vineyards were positioned on elevated sites. The complexes that are part of the Blue Class but situated outside this cluster are also built on former vineyards, orchards, or agricultural sites.

Other potential issues that these complexes could generate are related to the large number of apartments and visual blight (difference between the height of the multi-storey buildings and the neighbouring buildings), ranking second in each of these indicators, because of the emergence of multistorey blocks which shelter numerous apartments.

Although this class is prone to conflicts, it is notable that it achieves the lowest potential conflict values in terms of public transport, walkability index, average speed and time spent in traffic, denoting a satisfactory accessibility to the city centre either by car (high average speed and easily reachable) or by public transport. The occurrence of economic, leisure and education facilities within the new complexes diminishes the necessity of trips to the city core.

Although the Red Class does not stand out for a specific type of conflicts, it could be regarded as an average class, being prone to any conflict type in the peri-urban area, but at a lower intensity. A particularity of this class is that the complexes are located at the edge of the urban core, where most problems in terms of traffic could be encountered. An evidence of this phenomenon is observed in the case of average speed at rush hours, values revealing significant congestion.

However, a relatively favourable position according to the city centre brings satisfactory (but not as good as in the case of the Blue Class) results in terms of public transport access, time spent in traffic and walkability, if compared to the Green and Orange classes. Also, their structural attributes could be assessed as neighbourhood-friendly due to the low (but not far from the Blue and Orange Classes) number of apartments and visual blight values, which indicate a relatively satisfactory harmonization with the neighbourhood and conservation of the environment (also confirmed by the second-best ranking in terms of land use change, most residential units being developed on greenfields). The Green Class includes complexes of collective housing located, as in the previous case, at the edge of the urban core. As a result, accessibility has comparable, but slightly higher conflict values in terms of time spent in traffic, walkability, and average speed. In the case of the last indicator, it ranks the fourth out of the four classes. An identified particularity of this class is that most of the complexes are built on former industrial areas, which may bring both advantages and disadvantages. One specific feature of the complexes built on brownfields is the large availability of space that allows residential developers to project multistorey buildings, with a considerable high number of apartments, which may increase the existent problems of accessibility and decrease the average speed and also worsen the environmental issues such as noise and air pollution. As the chart shows (Fig. 5), the conflict 
indicators related to the number of apartments and height ratio unveil incomparably higher values than the rest of the classes. Being a former industrial area, walkability level is low because of the lack of facilities. However, favourable values are being achieved regarding the distance to public transport stations, as tram and bus stations have been implemented in the socialist era in order to facilitate the transportation of the workers from home to the industrial area. Also, it is notable that the index of land use changes records the lowest values due to the benefit brought by the renewal of repulsive areas.

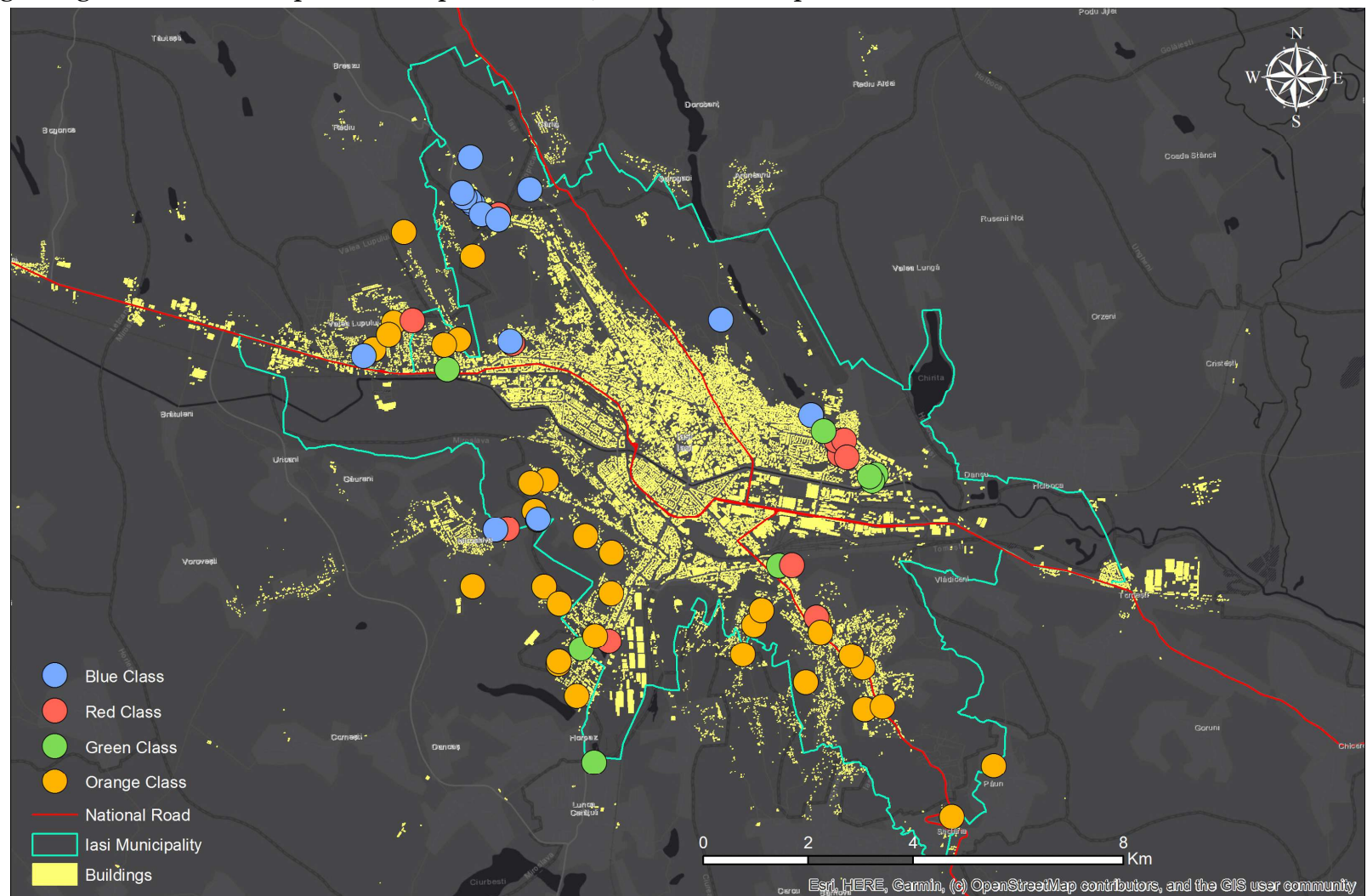

Fig. 4. Multivariate analysis of the complexes of collective housing in the peri-urban area of Iași Municipality.

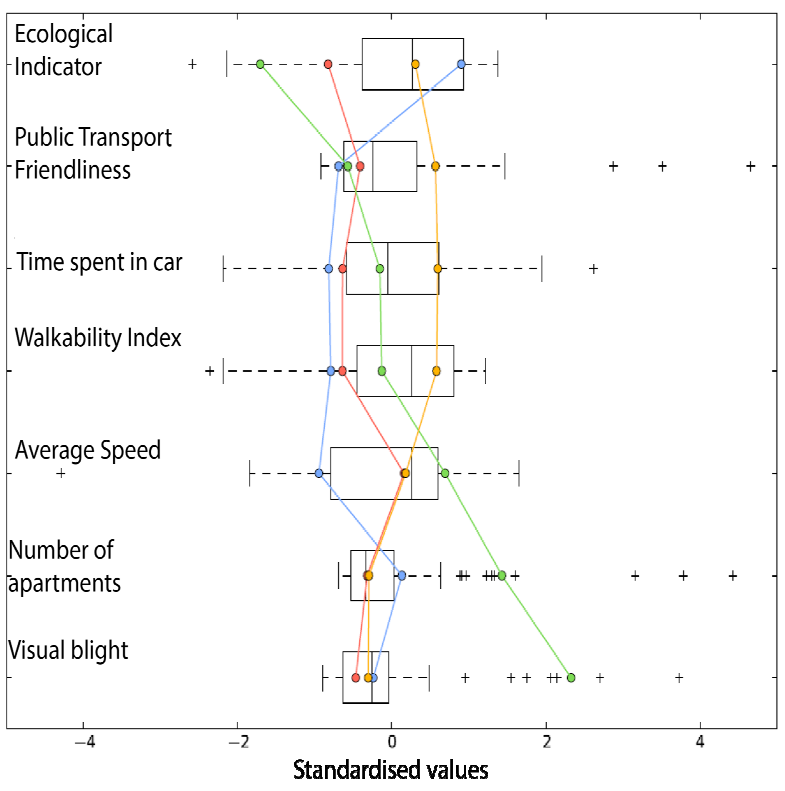

Fig. 5. Classes of conflicts generated by each indicator.

The complexes that fall into the Orange Class mostly cover the southern part of the city (with some exceptions in the western part). As the previous subsection unveiled that the most unsatisfactory values of the Conflict Index are encountered in the southern part, the multivariate analysis confirms the severe conflict probability of these residential units. Moreover, it is clear that this category includes the largest number of complexes (33), which comprises half of the analysis. This situation is a consequence of the lack of planning management in the peri-urban area, which leads to high exposure to conflicts for the complexes that fall into this category. Therefore, all indicators related to infrastructure record high potential conflict values, revealing the necessity to take immediate measures to increase the accessibility of the most problematic areas, which cover most of the suburbs.

The map (Fig. 4) reveals that a considerable large number of complexes are located outside the urban core, some exceeding the administrative border of Iaşi Municipality. As a result, they register by far the most unsatisfactory accessibility to public transport stations (some complexes being located even 4.5 kilometres to the nearest bus station), the most unsatisfactory walkability values, especially in the case of complexes built on greenfields, with no or few facilities and highest amounts of time spent in traffic in 
order to reach the city centre. Average speed of traffic at rush hours is also low ranked, creating congestion especially at the city entrances. The second worst ranking in the case of land use changes is a drawback of conversion of the agricultural sites in most of the cases. What is notable about these complexes is the fairly satisfactory structural indexes, as a result of the small dimension, reflecting a good height ratio to the buildings in the neighbourhood and the reduced number of apartments as well.

\subsection{Correlation between price per square metre and indicators}

In order to detect the extent to which the price of an apartment located in a complex of collective housing in the peri-urban area may be affected by its probability to generate conflicts, a statistical correlation between the Conflict Index and the price per square metre could provide the answer. The chart (Fig. 6) displays a relatively high correlation value between the two variables, which means that the market value of an apartment could give the potential buyer a hint about the risk of facing conflicts after moving into a specific complex. The negative trendline emphasizes that a more expensive apartment may ensure a lower susceptibility to conflicts than a cheap one.

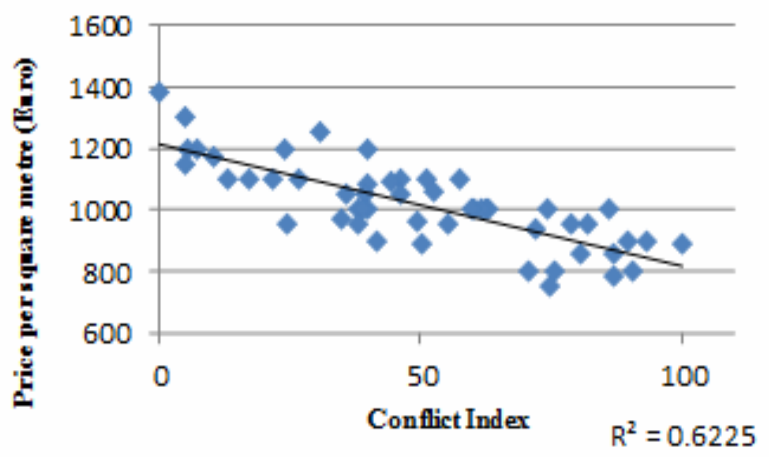

Fig. 6. Correlation between the Conflict Index and the price per square metre.

On the other hand, a potential customer of an inexpensive apartment in a complex of collective housing should be aware that a low price may denote an increased probability of encountering several conflicts. Table 2 unveils the correlation between the price per square metre and each of the variables taken into account for the Conflict Index in order to offer a more detailed view about the factors that weigh more in the price decrease. The obtained values could provide a relevant tool in detecting the most common conflicts brought by a lower price and also tend to confirm the assumptions based on the maps shown in the previous sections. To be more precise, it is clear that accessibility indicators exert the greatest impact on the sale price (if compared to the rest of the conflict triggers), which means that the location of a residential complex represents the most undeniable conflict generator. For example, the walkability index records the highest correlation value (-0.59), revealing that a low number or the lack of facilities in the neighbourhood of a complex considerably decreases the final price and raises the necessity of car trips in order to reach the desired facilities. As a result, an increased car dependency leads to a more significant amount of time spent in traffic and a lower average speed, these two conflict indicators being responsible for a significant price drop as well (-0.5 and -0.35). Moreover, public transport connectivity is also reflected in the market value: an apartment located within 500 metres distance to the nearest bus station is considered as being more valuable and less prone to conflicts than another that lacks this facility.

Table 2. Correlation between the price per square metre and each indicator.

\begin{tabular}{|l|r|}
\hline Walkability & -0.59 \\
\hline Time spent in car & -0.50 \\
\hline Public transport friendliness & -0.44 \\
\hline Average speed & -0.35 \\
\hline Apartments & -0.09 \\
\hline Visual blight & 0.02 \\
\hline Ecological indicator & -0.04 \\
\hline
\end{tabular}

Structural attributes like number of apartments and visual blight, as well as the ecological indicator, are not considered to affect the sale price to a high degree, although they trigger conflicts. In other words, residential developers set similar market values for both low-rise and high-rise buildings (located in similar spots), even though the ones from the last category exert an increased pressure on the environment and also induce visual blight to long-time residents. Land use change also has an insignificant effect on the final price, the buyer paying almost the same value either the complex is subject to conflicts of this type or not.

Considering all of the above, it is possible to assume that two identical complexes of collective housing may present radically different sale prices depending on their accessibility level. A favourable location requires an increased price as it delivers extra benefits to the resident and a lower chance to face conflicts. A cheap apartment is able to reflect only the value of the residential function, while the minimum utility of the space generates accessibility conflicts that involve extra costs in terms of time and money spent in order to benefit from basic daily facilities.

\section{CONCLUSIONS}

This article has brought new knowledge in the study of changing the territorial identity of post- 
socialist suburban districts by adopting an integrative approach. The case-study of Iaşi was used to analyse the alteration of suburbs in a post-socialist city which lacks planning trajectories for the functional urban areas. The analysis evaluates how new collective apartments impact the environment of the outskirts and reveals what type of buildings are most prone to generate conflicts in the suburbs. Moreover, the spatial location of the buildings is analysed in relation to the city and the facilities nearby.

The effect of the new collective apartments in the suburbs alters the already confused outskirts of the city. While the process of suburbanization delivered a chaotic planning in this area, mixing traditional houses with new residential lifestyle and agricultural practices with 21st century technological advances, the trigger of a new type of construction, namely collective housing, has scrambled even more the difficult task of evaluating the suburbs of Iași.

Evaluating the results, some buildings are contributing more to the pressure upon the environment and some less. Price per square metre is a valuable indicator to understand the effects of collective apartments. Cheaper apartments have a higher probability of generating diverse conflicts as they are situated a long distance away from the centre (more air/noise pollution), have fewer amenities (generating more movement toward the city and inducing a monocentric city) and are replacing a valuable resource for the environment (forest or crop). The more expensive apartments are located closer to the city; therefore, they are generating less traffic and they are connected to the urban transportation system. While buildings tend to have more apartments and greater visual blight, they also concentrate a diversity of facilities, which generates a more polynucleated city. Moreover, as they have facilities (i.e. sport facilities), there is an ease to generate community attachment and social interaction (Lund, 2002).

Land-use conflicts are a challenge for urban planners, especially in peri-urban areas. Planners need to analyse and understand these conflicts better in order to make optimal decisions on land-use allocations and conflict management. Such conflicts, however, are complex entities and they have to be addressed on a multidimensional scale. In the case of Iaşi, a good understanding of land-use conflicts is crucial for this task (Mann and Jeanneaux, 2009). Every conflict is unique and emerges from site-specific social, economic, and ecological interactions (Campbell, 1996).

However, the complexity of land-use conflicts in this case often conceals the necessary understanding (von der Dunk et al., 2011). While world planning trends aim at enhancing a sense of community through planning (Francis et al., 2012), in the specific case of Iaşi municipality, the lack of planning and the chaotic apparition of residential projects lead to a more 60 segregated and disrupted community. New residents regard the peri-urban zone as residential-only, while villagers are more sentimentally-attached (Wójcik, 2013) and tend to appreciate the value of socialisation to a higher extent (Tobiasz-Lis and Wójcik, 2017).

The emergence of collective buildings in remote undeveloped sites constrains their residents to depend on car mobility for any purpose, diminishing any chance of creating bonds with long-time residents and nature as well (Brown and Raymond, 2007). The exclusively residential function of these complexes restricts people to limit their peri-urban lifestyle only to the interior space of the apartment.

The indifference towards establishing a sense of community and a better connection with nature, together with the occurrence of collective buildings in areas of individual housing altered the territorial identity of the traditional village. Therefore, a space previously regarded as harmonious becomes subject to numerous conflicts, which demand feasible - and collaborative planning management to minimise the existent drawbacks and prevent the potential ones according to location. In order to achieve this goal, researchers emphasize the decisive role of nature in maintaining the territorial identity of villages, which should guide the stakeholders in creating a resilient and sustainable future of the rural and peri-urban areas (Banini and Ilovan, 2021). Therefore, the presence of open areas and a harmonious relationship among people, as well as between people and the environment should represent the pillars of an adequately planned village (Banini and Ilovan, 2021).

\section{REFERENCES}

Bailoni M., Edelblutte S., Tchékémian A. (2012), Agricultural landscapes, heritage and identity in periurban areas in Western Europe 15. European Countryside, $\quad 4(2)$, 147-161. DOI: https://doi.org/10.2478/v10091-012-0020-9.

Banini T. (2017), Proposing a theoretical framework for local territorial identities: concepts, questions and pitfalls. Territorial Identity and Development, 2(2), 1623. DOI: $10.23740 / T I D 220172$.

Banini T., Ilovan O.-R. (2021), Conclusions: towards a new agenda for place/territorial identity research. In: Banini T., Ilovan O.-R. (eds.), Representing Place and Territorial Identities in Europe. GeoJournal Library, vol. 127. Springer, Cham, 251-265, DOI: https://doi.org/10.1007/978-3-030-66766-5_17.

Bertaud A. (2006), The spatial structures of Central and Eastern European Cities. In: Tsenkova S., Nedović-Budić Z. (eds.), The Urban Mosaic of Post-Socialist Europe, Contributions to Economics. Physica-Verlag HD, 91-110. DOI: https://doi.org/10.1007/3-7908-1727-9_5.

Bîrsănuc E.-M., Man T.-C., Petrea D. (2019), What does unsustainable urban sprawl bring? Spatial 
patterns analysis of built environment in Cluj Metropolitan Area. Journal of Settlements and Spatial Planning, $\quad 10(2), \quad 121-130 . \quad$ DOI: https://doi.org/10.24193/JSSP.2019.2.05.

Blăgeanu A., Iacob I. C., Roșu L. (2012), Simulation of suburban development features based on scenarios in the eastern side of Iasi City. Geographia Napocensis, 6(2), 130-139.

Brown G., Raymond C. (2007), The relationship between place attachment and landscape values: toward mapping place attachment. Applied Geography, 27, 89111. DOI: 10.1016/j.apgeog.2006.11.002.

Burton E., Jenks M., Williams K. (eds.) (2013), Achieving Sustainable Urban Form. Routledge, London. ISBN: 9780419244509.

Campbell S. (1996), Green cities, growing cities, just cities? Urban planning and the contradictions of sustainable development. Journal of the American Planning Association 62, 296-312. DOI: https://doi.org/10.1080/01944369608975696.

Caruso G., Rounsevell M., Cojocaru G. (2005), Exploring a spatio-dynamic neighbourhood based model of residential behaviour in the Brussels periurban area. International Journal of Geographical Information Science 19, 103-123. DOI: https://doi.org/10.108o/13658810410001713371.

Dumitrache L., Zam D., Simion G., Stoica I. V. (2016), The urban nexus: contradictions and dilemmas of (post)communist (sub)urbanization in Romania. Human Geographies - Journal of Studies and Research in Human Geography, 10(1), 39-58. DOI: 10.5719/hgeo.2016.101.3.

ESPON Report (2012), Second Tier Cities and Territorial Development in Europe: Performance, Policies and Prospects. ESPON \& European Institute of Urban Affairs, Liverpool, John Moores University. URL: https://www.espon.eu/sites/default/files/attachments/S GPTD_Final_Report_-_Final_Version_27.09. 12.pdf. Accessed on 12.01.2021.

Francis J., Giles-Corti B., Wood L., Knuiman M. (2012), Creating sense of community: the role of public space. Journal of Environmental Psychology, 32(4), 401409. DOI: https://doi.org/10.1016/j.jenvp.2012.07.002.

Gogtay N. J., Thatte U. M. (2017), Principles of correlation analysis. Journal of The Association of Physicians of India, 65(3), 78-81.

Grădinaru S. R., Iojă C. I., Onose D. A., Gavrilidis A. A., Pătru-Stupariu I., Kienast F., Hersperger A. M. (2015), Land abandonment as a precursor of built-up development at the sprawling periphery of former socialist cities. Ecological Indicators, $\quad 57, \quad 305-313$. $\quad$ DOI: https://doi.org/10.1016/j.ecolind.2015.05.009.

Grădinaru S. R., Iojă C. I., Pătru-Stupariu I. (2015), Do Post-socialist urban areas maintain their sustainable compact form? Romanian urban areas as case study. Journal of Urban and Regional Analysis, 7(2), 129-144. DOI: 10.37043/JURA.2015·7.2.2.

Grigorescu I., Mitrică B., Kucsicsa G., Popovici E.-A., Dumitraşcu M., Cuculici R. (2012), Postcommunist land use changes related to urban sprawl in the Romanian metropolitan areas. Human Geographies - Journal of Studies and Research in Human Geography, 6(1), 35-46. DOI: https://doi.org/10.5719/hgeo.2012.61.35.

Hirt S. (2007), Suburbanizing Sofia: characteristics of post-socialist peri-urban change. Urban Geography, 28, 755-780. DOI: https://doi.org/10.2747/02723638.28.8.755.

Hirt S. (2013), Whatever happened to the (post)socialist city? Cities, 32, 29-38. DOI: https://doi.org/10.1016/j.cities.2013.04.010.

Iacob C., Roşu L., Blăgeanu A. (2012), Cellular automata for urban growth. Geographica Timisiensis, 79-88.

Ianoş I., Peptenatu D., Drăghici C., Pintilii R. D. (2020), Management elements of the emergent metropolitan areas in a transition country. Romania, as case study. Journal of Urban and Regional Analysis, 4(2). DOI: https://doi.org/10.37043/JURA.2012.4.2.3.

Ilovan O.-R., Maroşi Z. (2018), Markers of visual identity: industrial sites and landscapes in picture postcards during the socialist period of Romania. Acta Technica Napocensis: Civil Engineering \& Architecture, 61(3), 132-151.

Iojă C. I., Niţă M. R., Vânău G. O., Onose D. A., Gavrilidis A. A. (2014), Using multi-criteria analysis for the identification of spatial land-use conflicts in the Bucharest Metropolitan Area. Ecological Indicators, 42, 112-121.

DOI:

https://doi.org/10.1016/j.ecolind.2013.09.029.

Iojă C. I., Onose D. A., Nita M. R., Vanau G. O., Patroescu M., Gavrilidis A. A., Saghin I., Zarea R. (2011), The conversion of agricultural lands into built surfaces in Romania. In: Niola V., Kala T., Popescu C. (eds.), Recent Researches in Urban Sustainability and Green Development, 115-120. WSEAS Press, Athens. ISBN: 978-1-61804-037-4.

Iojă C. I., Patroescu M., Rozylowicz L., Nita M. R., Ioja A., Patroescu-Klotz I. (2012), Evaluarea integrată a stării mediului în spaţiile rezidenţiale (Integrated Assessment of the Environment in Residential Spaces). Editura Academiei Romane, București. [Book in Romanian] DOI: https://doi.org/10.13140/2.1.3408.0327.

Kalandides A. (2011), The problem with spatial identity: revisiting the "sense of place". Journal of Place Management and Development, 4(1), 28-39. https://doi.org/10.1108/17538331111117142.

Kontgis C., Schneider A., Fox J., Saksena S., Spencer J. H., Castrence M. (2014), Monitoring periurbanization in the greater Ho Chi Minh City 
Metropolitan Area. Applied Geography 53, 377-388. DOI: https://doi.org/10.1016/j.apgeog.2014.06.029.

Korcelli P. (1990), Recent urban and population change in Poland. Geoforum, 21(2), 173-184, DOI: https://doi.org/10.1016/0016-7185(90)90036-6.

Larcombe D. L., van Etten E., Logan A., Prescott S. L., Horwitz P. (2019), High-rise apartments and urban mental health-historical and contemporary views. Challenges, 10(2), 34. DOI: https://doi.org/10.3390/challe10020034.

Light D., Young C. (2010), Reconfiguring Socialist urban landscapes: the 'left-over' spaces of statesocialism in Bucharest. Human Geographies, 4(1), 5-16.

Lityński P., Hołuj A. (2017), Urban sprawl costs: the valuation of households' losses in Poland. Journal of Settlements and Spatial Planning, 8(1), 11-35. DOI: https://doi.org/10.24193/JSSP.2017.1.02.

Liu Z., Robinson G. M. (2016), Residential development in the peri-urban fringe: the example of Adelaide, South Australia. Land Use Policy, 57, 179-192. DOI: https://doi.org/10.1016/j.landusepol.2016.05.026 Lund H. (2002), Pedestrian environments and sense of community. Journal of Planning Education and Research, 21(3), 301-312. DOI: 10.1177/0739456X 0202100307.

Maclennan D. (1982), Housing economics: an applied approach. Longman, London \& New York. ISBN: 9780582443815 .

Madaleno I. M., Gurovich A. (2004), "Urban versus rural" no longer matches reality: an early public agroresidential development in periurban Santiago, Chile. Cities, 21(6), 513-526. DOI: https://doi.org/10.1016/j.cities.2004.08.001.

Manaugh K., El-Geneidy A. (2011), Validating walkability indices: How do different households respond to the walkability of their neighborhood? Transportation Research Part D: Transport and Environment, 16(4), 309-315.

Mann C., Jeanneaux P. (2009), Two approaches for understanding land-use conflict to improve rural planning and management. Journal of Rural and Community Development, 4(1), 118-141.

Mihai C. (2015), Morpho-Functional Dynamics of Iasi Municipality After 1990 - Process, Structures and Spatial Challenges, Alexandru Ioan Cuza University of Iasi, Faculty of Geography and Geology, Iasi, Romania $\mathrm{PhD}$ Thesis [in Romanian].

Mulder K., Costanza R., Erickson J. (2006), The contribution of built, human, social and natural capital to quality of life in intentional and unintentional communities. Ecological Economies, 59, 13-23. DOI: https://doi.org/10.1016/j.ecolecon.2005.09.021.

Orford S. (1999), Valuing the Built Environment. GIS and House Price Analysis. Ashgate Publishing, Farnham. ISBN: 978-0-7546-1012-o (hbk).

Pigawati B., Yuliastuti N., Mardiansjah F. H. (2019), Settlements growth and development in 62
Semarang City Centre Area, Indonesia. Journal of Settlements and Spatial Planning, 10(2), 99-109. DOI: https://doi.org/10.24193/JSSP.2019.2.03.

Roșu L. I., Blăgeanu A. (2015), Evaluating issues and performance of a public transport network in a post-communist city using a quantitative spatial approach. Urbani izziv, 26(2), 103-116. DOI: 10.5379/urbani-izziv-en-2015-26-02-002.

Roșu L., Istrate M., Bănică A. (2018), Passenger car dependency and consequent air pollutants emissions in Iasi Metropolitan Area (Romania). Environmental Engineering \& Management Journal (EEMJ), 17(4), 865-875. DOI: 10.30638/eemj.2018.087.

Sandric I., Mihai B., Savulescu I., Suditu B., Chitu, Z. (2007), Change detection analysis for urban development in Bucharest-Romania, using high resolution satellite imagery. 2007 Urban Remote Sensing Joint Event, 1-8. DOI: https://doi.org/10.1109/URS.2007.371848.

Sheppard E. (2000), Socialist cities? Urban Geography, 21(8), 758-763. DOI: https://doi.org/10.2747/0272-3638.21.8.758.

Short J., Basset K. (1980), Housing and Residential Structure: Alternative Approaches. Routledge, S.L. ISBN: 9780367756673 .

Simion G. (2010), The Spatial Changes of Land Use in the Bucharest Metropolitan Area 1970s - 2000s. Human Geographies - Journal of Studies and Research in Human Geography, 4(2), 115-123. DOI: https://doi.org/10.5719/hgeo.2010.42/115.

Stan O. M. (2012), Construcţia neo-ruralului la porţile oraşului: Vectorii satisfacţiei rezidenţiale în suburbiile emergente [The construction of the new rural at the city gates: vectors of residential satisfaction in emerging suburbs]. Sociologie Românească, 10(1), 89-114. [Article in Romanian].

Stanilov K. (ed.) (2007), The Post-Socialist City: Urban Form and Space Transformations in Central and Eastern Europe after Socialism. GeoJournal Library. Springer, Dordrecht. ISBN: 978-1-4020-6053-3.

Stanilov K., Sykora L. (eds.) (2014), Confronting Suburbanization: Urban Decentralization in Postsocialist Central and Eastern Europe, Studies in Urban and Social Change. Wiley-Blackwell, Malden, MA. ISBN: 978-14051-8548-6.

Suditu B. (2009), Urban sprawl and residential mobilities in the Bucharest Area - reconfiguration of a new residential geography. Human Geographies Journal of Studies and Research in Human Geography, 3(2), 79-93.

Suditu B., Ginavar A., Muică A., Iordăchescu C., Vârdol A., Ghinea B. (2010), Urban sprawl characteristics and typologies in Romania. Human Geographies - Journal of Studies and Research in Human Geography, 4(2), 79-87.

Suditu B., Nae M., Neguţ S., Dumitrache L., Gheorghilaş A. (2014), Suburban landscapes in 
Romania from 'forting-up' to 'informal-up' and limits of public action. European Journal of Science and Theology, 10(5), 125-138.

Tobiasz-Lis P., Wójcik M. (2017), Representations of rural settlements in the debate of multifunctional countryside. Example of Poland. Bulletin de la Société Géographique de Liège, 69, 29-39. DOI: 10.25518/0770-7576.4658.

Ursu A., Burţilă R., Minea V., Marius A., Ichim P. (2015), Urban public transportation system changes, in post-communist period in Iasi Municipality. $15^{\text {th }}$ International Multidisciplinary Scientific GeoConference SGEM, 18-24. ISBN: 978-1-4051-8547-9.
Ursu A., Andrei M., Chelaru D. A., Ichim P. (2016), Built-up area change analysis in Iasi City using GIS. Present Environment and Sustainable Development, $\quad 10(1), \quad$ 201-216. DOI: https://doi.org/10.1515/pesd-2016-0018.

von der Dunk A., Grêt-Regamey A., Dalang T., Hersperger A. M. (2011), Defining a typology of periurban land-use conflicts - a case study from Switzerland. Landscape and Urban Planning, 101, 149156. DOI: 10.1016/j.landurbplan.2011.02.007.

Wójcik M. (2013), Territorial identity of countryside residents in the suburban areas of Łódź, Poland. Quaestiones Geographicae, 32(2), 69-79. DOI: 10.2478/quageo-2013-0014, ISSN: 0137-477X. 